\title{
The Anti-viral Action of Rutilantin A
}

\author{
BY VALERIE HUME*, J. C. N. WESTWOOD AND G. APPLEYARD \\ Microbiological Research Establishment, Porton, Wiltshire
}

(Received 26 August 1964)

\begin{abstract}
SUMMARY
Rutilantin A has been tested for antiviral activity in vitro. This antibiotic had no demonstrable effect on the growth of poliomyelitis or influenza viruses, but it completely inhibited the multiplication of rabbitpox virus. It was effective against rabbitpox virus when added to tissuecell cultures as late as $4 \mathrm{hr}$ after infection. The lowest concentration of rutilantin that prevented the formation of infective rabbitpox virus did not apparently affect the synthesis of viral DNA or soluble antigens. It is concluded that rutilantin inhibits a late stage of virus development. The toxicity of rutilantin for both cultured tissue cells and animals makes it unlikely to be of value in the treatment of virus disease.
\end{abstract}

\section{INTRODUCTION}

Asheshov, Strelitz, Hall \& Flon (1954) made a survey of about 1000 strains of actinomycetes in a search for antibiotics with anti-viral activity. Bacteriophages were used as the test organisms, and some 140 strains of actinomycetes were found which produce substances inhibitory of phage replication. From one of these, strain A 220, rutilantin $\mathbf{A}$ was isolated and purified by the Medical Research Council Antibiotics Station at Clevedon. The chemical structure of rutilantin, which is related to the anthraquinones, has been intensively studied by Ollis and his coworkers (Ollis \& Sutherland, 1961). While the anti-phage activity of rutilantin was clear-cut (Asheshov \& Gordon, 1961), its activity against animal viruses was more doubtful. Tests on unpurified material were made through the courtesy of Dr J. Spizizen (Merck, Sharp and Dohme, Inc.) and of Dr P. K. Smith (George Washington School of Medicine, Washington, D.C., U.S.A), but the results were inconclusive and varied from batch to batch. Accordingly, the present work was undertaken with pure crystalline rutilantin A kindly supplied by $\mathrm{Dr}$ W. D. Ollis of Bristol University.

\section{METHODS}

Rutilantin. Crystalline rutilantin A was dissolved in $0 \cdot 01 \mathrm{~N}-\mathrm{HCl}$ at a concentration of $5 \mathrm{mg}$. $/ \mathrm{ml}$. and the solution then adjusted to $\mathrm{pH} 5 \cdot 4$. This stock solution was stored at $-80^{\circ}$, and was diluted appropriately in medium as required. Alternatively, a solution of $1 \mathrm{mg} . / \mathrm{ml}$. was made in acetone immediately before use, and then diluted in medium.

Tissue culture cells. $R K$ 13. A cell line derived from rabbit kidney was kindly supplied by Mr G. Christofinis (Glaxo Laboratories Ltd.). The cells were cultured in medium ' 199 ' containing $10 \%(\mathrm{v} / \mathrm{v})$ calf serum. HeLa $(E R K)$. This cell line was

* Present address: Bacteriology Department, University of Edinburgh, Edinburgh 8. 


\section{V. Hume, J. C. N. Westwood and G. Appleyard}

maintained in Porton calf serum medium as previously described (Appleyard \& Westwood, 1964). $C E / P$. Primary chick cultures were prepared by trypsinization of 10-day embryos followed by growth of the cells in Porton calf serum medium. All three types of tissue culture were normally grown as monolayers in $8 \mathrm{~cm}$. Carrel flasks. For the few experiments that entailed microscopic examination of RK 13 cultures for viral DNA, the cells were inoculated onto coverslips in the bottom of Petri dishes.

Viruses. Influenza virus. The WS strain of virus was used. It was propagated in the allantoic cavity of fertile hen eggs. Poliovirus. This was the Brunhilde strain of type 1 virus. It was maintained by passage in $\mathrm{HeLa}$ (ERK) cells. Rabbitpox virus. The Utrecht strain of virus was grown in HeLa (ERK) cells. Virus was liberated from the infected cells by ultrasonic treatment, to produce a stock suspension with a titre of $10^{8}$ plaque forming units $(\mathrm{pfu}) / \mathrm{ml}$.

\section{Inhibition of rabbitpox virus}

Virus growth. For reasons to be discussed under 'Results', the effect of rutilantin on the growth of rabbitpox virus was studied in RK 13 cells. These were infected at $4^{\circ}$ by the inoculation of $4 \mathrm{ml}$. virus suspension of titre $10^{8} \mathrm{pfu} / \mathrm{ml}$. onto confluent Carrel flask cultures containing about $6 \times 10^{6}$ cells. After an adsorption period of $1 \mathrm{hr}$ the excess virus was removed by two washes with phosphate buffered saline, fresh medium was added, and cultures incubated at $36^{\circ}$. Since rabbitpox virus adsorbs to but does not penetrate cells at $4^{\circ}$ (Appleyard \& Westwood, 1964), the amount of infecting virus could be determined directly by titration of sample cultures at the end of the adsorption period; it was usually 2 to $3 \mathrm{pfu} / \mathrm{cell}$. All virus growth periods were measured from the time at which the cultures were warmed to $36^{\circ}$.

Virus titration. For the assessment of virus yield from individual cultures, cells were scraped from the glass and then disintegrated by ultrasonic treatment with a $500 \mathrm{~W}$. 'Soniclean' generator at $40 \mathrm{kcyc} / \mathrm{sec}$. (Dawe Instruments, Ltd., London). Virus was titrated as pfu in HeLa (ERK) monolayers by the method of Appleyard \& Westwood (1964).

Detection of viral antigens. Cells from infected cultures were concentrated to $4 \times 10^{7} / \mathrm{ml}$. by centrifugation, and then disrupted by ultrasonic treatment. The resulting extracts were examined for soluble viral antigens by micro-immunodiffusion (Crowle, 1958) against hyperimmune rabbitpox serum.

Detection of viral $D N A$. Coverslip cultures of RK 13 cells were infected by the adsorption of $0 \cdot 2 \mathrm{ml}$. rabbitpox virus suspension of titre $10^{8} \mathrm{pfu} / \mathrm{ml}$. for $1 \mathrm{hr}$ at $4^{\circ}$. They were then washed, and incubated in medium at $36^{\circ}$. Sample cultures were withdrawn at intervals, washed, fixed in absolute ethanol and stained with a solution of acridine orange in methanol (Randles, 1960). The coverslips were mounted in liquid paraffin, and examined under dark-ground ultraviolet illumination for the presence of green cytoplasmic inclusions. 


\section{RESULTS}

Effect of rutilantin on tissue cells

Toxicity. The toxicity of rutilantin was tested on RK 13, HeLa (ERK) and CE/P cell cultures in order to select the most suitable system for further experiments. A range of concentrations of rutilantin, from 0.1 to $100 \mu \mathrm{g} . / \mathrm{ml}$., was added to actively growing cultures of each cell type, and incubation was continued for $24 \mathrm{hr}$. At a concentration of $100 \mu \mathrm{g} . / \mathrm{ml}$., crystalline rutilantin was deposited both intraand extracellularly; in all three cell types gross abnormalities appeared, and the cells became rounded and stripped from the glass. The toxic effect was decreased with decreasing concentrations of rutilantin, but in HeLa (ERK) and CE/P cultures it was still evident at $0 \cdot 1 \mu \mathrm{g} . / \mathrm{ml}$. Cultures of RK 13 on the other hand were less susceptible. Those treated with concentrations of $0 \cdot 1$ and $1 \mu \mathrm{g} . / \mathrm{ml}$. appeared morphologically normal, although cell division either ceased or was considerably reduced. From these results it was decided to use where possible the RK 13 cell line as the test tissue culture system, with concentrations of rutilantin not exceeding $1 \mu \mathrm{g} . / \mathrm{ml}$.

Irreversibility of toxic effect. Rutilantin was clearly a highly cytotoxic material. From the point of view of its possible value as a chemotherapeutic agent, it was desirable to know whether the toxic effect could be annulled by removal of the drug from the cellular environment. The concentration of rutilantin chosen for this test was $0 \cdot 2 \mu \mathrm{g} . / \mathrm{ml}$. since this was found, as discussed below, to be the minimum concentration that inhibited the growth of rabbitpox virus.

Table 1. Failure of $R K 13$ cells to recover from the toxic effect of rutilantin

\begin{tabular}{|c|c|c|c|}
\hline \multirow[b]{2}{*}{$\begin{array}{c}\text { Incubation } \\
\text { period } \\
\text { (hr) }\end{array}$} & \multicolumn{3}{|c|}{ Number of living cells* per culture $\left(\times 10^{-6}\right)$} \\
\hline & $\begin{array}{l}\text { Control } \\
\text { cultures }\end{array}$ & $\begin{array}{c}\text { Test cultures } \\
\text { (rutilantin } \\
0 \cdot 2 \mu \mathrm{g} . / \mathrm{ml} . \text { ) }\end{array}$ & $\begin{array}{l}\text { Test cultures } \\
\text { after further } \\
\mathbf{4 8} \mathrm{hr} \text { without } \\
\text { rutilantin }\end{array}$ \\
\hline $\mathbf{0}$ & $6 \cdot 5$ & $6 \cdot 5$ & 一 \\
\hline 24 & $7 \cdot 5$ & $3 \cdot 9$ & $\mathbf{3} \cdot \mathbf{3}$ \\
\hline 72 & 14.5 & $\mathbf{2 \cdot 9}$ & $2 \cdot 0$ \\
\hline
\end{tabular}

Actively growing cultures of RK 13 cells were incubated in medium with or without rutilantin $0.2 \mu \mathrm{g} . / \mathrm{ml}$. for $24 \mathrm{hr}$ or $72 \mathrm{hr}$ at $36^{\circ}$. After this exposure period the rutilantin-containing medium was replaced by normal medium, and incubation was continued for a further $48 \mathrm{hr}$ 'recovery' period. Cell counts were made on control and test cultures at 0,24 and $72 \mathrm{hr}$ and again on the test cultures after the recovery period. The results are shown in Table 1 . It can be seen that cell replication stopped on addition of rutilantin to the cultures, and growth was not reestablished even when the drug was removed after only $24 \mathrm{hr}$.

\section{Effect of rutilantin on the growth of influenza virus}

The possible inhibitory effect of rutilantin on the WS strain of influenza virus was tested in the allantoic cavity of 10-day chick embryos. In several experiments, 
infectivity titrations were carried out simultaneously in groups of untreated eggs and in eggs inoculated with up to $10 \mu \mathrm{g}$. rutilantin. No evidence of protection was obtained. In one experiment, three groups of ten eggs were inoculated with 1, 5 or $10 \mu \mathrm{g}$. rutilantin/egg and then challenged with approximately 200 EID50 of virus; five eggs, treated with saline only, served as controls. All eggs, except for five that died, were found to be infected when tested after $48 \mathrm{hr}$ incubation. Haemagglutinin titrations on the allantoic fluids from individual eggs showed further that the virus yield was not significantly reduced by treatment with rutilantin.

\section{Effect of rutilantin on the growth of poliovirus}

Because of the toxicity of rutilantin for HeLa (ERK) cells, the only available cell line that was susceptible to infection with poliovirus, satisfactory tests on the inhibition of poliovirus were difficult to perform. However, a single experiment was set up to indicate whether further work might usefully be done. Six Petri dishes were seeded with a suspension of HeLa (ERK) cells in $1 \%$ agar. Three of the cultures were infected by the inclusion of about 500 p.f.u. poliovirus in the suspension, according to the plaque technique of Cooper (1955). Rutilantin at concentrations of 10 or $500 \mu \mathrm{g} . / \mathrm{ml}$. was added to $9 \mathrm{~mm}$. diameter wells cut in the centre of each of two cultures, one infected and the other uninfected. The cultures were incubated for 3 days at $36^{\circ}$, and then stained with a tetrazolium derivative to differentiate living from dead cells. In the uninfected cultures, the toxicity of rutilantin was shown by an inner zone of complete clearing around the central well and a wider outer zone of partial clearing which extended to a diameter of $25 \mathrm{~mm}$. in the plate with the higher dose of rutilantin. In the infected cultures, poliovirus plaques of apparently normal size and number could be seen extending right up to the inner zone of complete clearing of the cells. The results of this experiment seemed to indicate that rutilantin was more toxic to the cells than to the virus, and therefore no further tests were carried out.

\section{Effect of rutilantin on the growth of rabbitpox virus}

In contrast to its apparent lack of action against the other two viruses, rutilantin was found to have a definite inhibitory effect on the growth of rabbitpox virus. Experiments were therefore made to define its effectiveness and indicate its mode of action.

Dose-response curve. The effect of rutilantin on rabbitpox virus replication was tested over a range of concentrations from 0.008 to $1.0 \mu \mathrm{g} . / \mathrm{ml}$. Medium containing the inhibitor was added to RK 13 cultures after infection with virus at $4^{\circ}$, and the virus yield was determined after incubation for $22 \mathrm{hr}$ at $36^{\circ}$. The results of three experiments are shown together in Fig. 1. At a concentration of $0 \cdot 4 \mu \mathrm{g} . / \mathrm{ml}$, rutilantin completely suppressed virus multiplication, so that less than 1 p.f.u./cell could be recovered. In presence of rutilantin $0 \cdot 2 \mu \mathrm{g} . / \mathrm{ml}$. virus growth was either greatly decreased or completely prevented.

Irreversibility of inhibitory action. It had been found that the toxic effect of rutilantin on RK 13 cells was not annulled by withdrawal of the drug from the culture medium. An experiment was therefore set up to determine whether the inhibition of virus replication was similarly irreversible. Two test cultures were 
incubated for $3 \mathrm{hr}$ in medium containing rutilantin $1 \mu \mathrm{g} . / \mathrm{ml}$. After a further $3 \mathrm{hr}$ in normal medium, the cultures were infected with rabbitpox virus at $4^{\circ}$. One culture was harvested immediately and the other incubated for $22 \mathrm{hr}$ at $36^{\circ}$ to allow virus growth. Three control cultures, which had not been exposed to rutilantin, were infected in parallel with the test cultures. One was harvested immediately after virus adsorption, one after incubation for $22 \mathrm{hr}$ in normal medium, and, to check the inhibitory action of the rutilantin, one was incubated for $22 \mathrm{hr}$ in medium containing rutilantin $1 \mu \mathrm{g} . / \mathrm{ml}$. The results (Table 2 ) showed that pretreatment of cells with rutilantin was completely effective in suppressing virus growth. It therefore seems that the inhibition of virus replication was brought about by some alteration in the cells which, like the toxic effect of rutilantin, was not annulled by removal of the drug. The fact that the same amount of virus was adsorbed by control and test cultures indicates that pretreatment of cells with rutilantin did not interfere with virus adsorption.

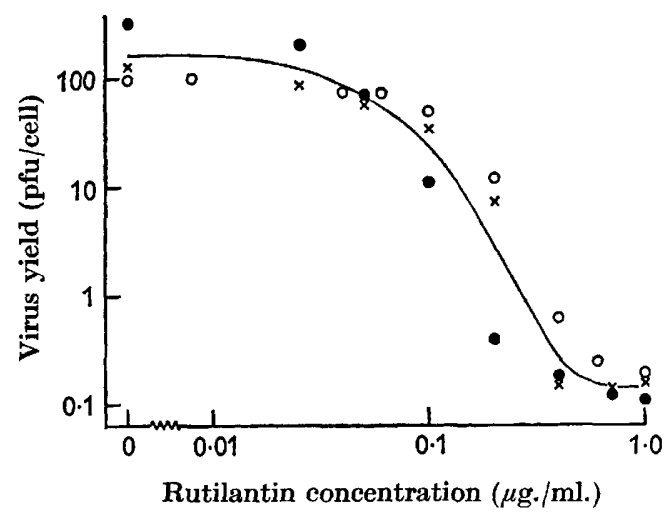

Fig. 1

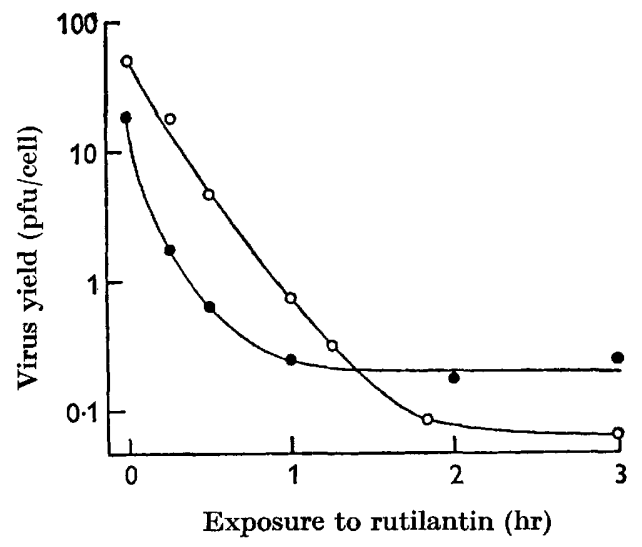

Fig. 2

Fig. 1. Effect of rutilantin concentration on the yield of rabbitpox virus from $\mathbf{R K} 13$ cultures. The symbols $O$, and $\times$ represent the results of three separate experiments. Fig. 2. Effect of duration of pretreatment with rutilantin on the yield of rabbitpox virus from RK 13 cultures. Rutilantin concentration: $\bigcirc, 0.75 \mu \mathrm{g} . / \mathrm{ml}$; $0,1.0 \mu \mathrm{g} . / \mathrm{ml}$.

Table 2. Inhibition of rabbitpox virus growth by pretreatment of RK 13 cultures with rutilantin

Control

Culture

Rutilantin $1 \mu \mathrm{g} . / \mathrm{ml}$. during virus growth Rutilantin $1 \mu \mathrm{g} . / \mathrm{ml}$. before virus growth

\begin{tabular}{|c|c|}
\hline \multicolumn{2}{|c|}{ Time of test } \\
\hline $0 \mathrm{hr}$ & $22 \mathrm{hr}$ \\
\hline \multicolumn{2}{|c|}{ Virus titre (p.f.u. per cell } \\
\hline $2 \cdot 5$ & 247 \\
\hline $2 \cdot 5$ & 0.11 \\
\hline $2 \cdot 4$ & 0.24 \\
\hline
\end{tabular}

Two further experiments were made to determine the duration of exposure to rutilantin that was necessary to prevent virus growth. Cultures were treated with rutilantin, either 0.75 or $1.0 \mu \mathrm{g} . / \mathrm{ml}$., for various lengths of time, and $2 \mathrm{hr}$ after removal of the drug they were infected with rabbitpox virus. The virus yields after 
growth for $18 \mathrm{hr}$ are shown in Fig. 2. Almost complete inhibition was caused by exposure to rutilantin $1 \mu \mathrm{g} . / \mathrm{ml}$. for $\frac{1}{2} \mathrm{hr}$ or $0.75 \mu \mathrm{g} . / \mathrm{ml}$. for $1 \mathrm{hr}$. It is not known whether these times represent mainly the time taken for the drug to penetrate the cells or that required for it to exert its action when it is already intracellular.

\section{Mode of action of rutilantin}

Direct action on virus infectivity. Samples of a rabbitpox virus suspension of titre $1.5 \times 10^{6} \mathrm{p}$. .f.u. $/ \mathrm{ml}$. were incubated for $1 \mathrm{hr}$ at $36^{\circ}$ with various concentrations of rutilantin up to $100 \mu \mathrm{g} . / \mathrm{ml}$. Each sample was then diluted by a factor of $10^{4}$ and inoculated on to Petri dish cultures of HeLa (ERK) cells for the titration of surviving virus. There was no significant difference between the titres of the treated virus and that of control virus incubated without rutilantin. Rutilantin therefore exerted no direct viricidal effect even at concentrations far in excess of those required to suppress virus replication.

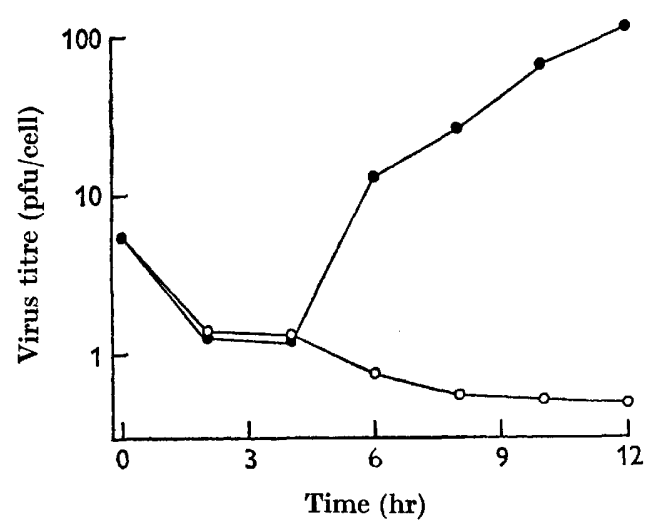

Fig. 3

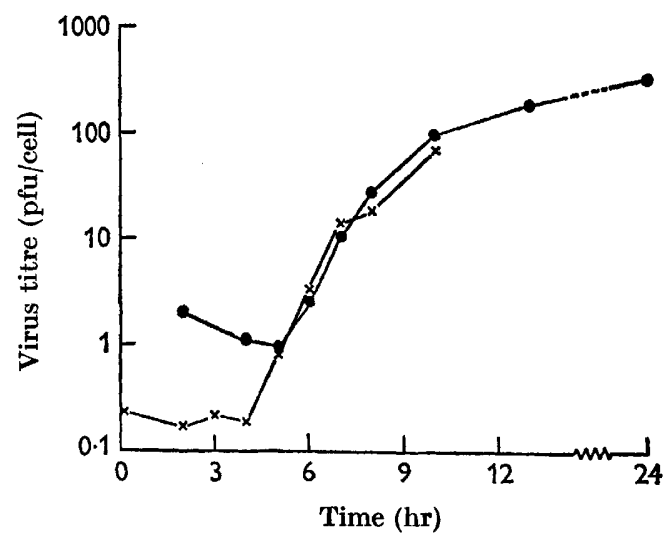

Fig. 4

Fig. 3. One-step growth curves of rabbitpox virus in RK 13 cells. O, normal growth; $O$, growth in the presence of rutilantin $0 \cdot 2 \mu \mathrm{g} . / \mathrm{ml}$.

Fig. 4. Effect of time of addition of rutilantin on the yield of rabbitpox virus from RK 13 cultures. - normal growth curve; $\times$, virus yield at $24 \mathrm{hr}$ after addition of rutilantin $0.4 \mu \mathrm{g} . / \mathrm{ml}$. at times shown.

Action on virus penetration and eclipse. One-step virus growth curves were made in presence or absence of rutilantin $0 \cdot 2 \mu \mathrm{g} . / \mathrm{ml}$. (Fig. 3). The results suggest that virus penetration and eclipse took place normally in the presence of rutilantin, but that no new infective virus was formed.

Action on intracellular replication. To determine the sensitive stage of virus growth, rutilantin $0.4 \mu \mathrm{g} . / \mathrm{ml}$. was added to cultures at various times after infection, and the final yields of virus from the cultures were titrated after incubation for $24 \mathrm{hr}$. In addition, other infected cultures were harvested at intervals and titrated to show the normal virus growth curve (Fig. 4). Rutilantin was completely effective in preventing the formation of new virus when added as late as $4 \mathrm{hr}$. after infection of the cultures, and only a small amount of virus was produced when it was added at $5 \mathrm{hr}$. Rutilantin therefore exerts its inhibitory effect very late in the virus growth cycle.

Action on synthesis of viral protein. The development of soluble viral antigens 
during the course of infection was taken as an indication of the synthesis of viral protein. Infected cell cultures were incubated for $24 \mathrm{hr}$ in normal medium or in medium with concentrations of rutilantin from 0.1 to $1.0 \mu \mathrm{g} . / \mathrm{ml}$. The yields of virus from the cultures were those shown by the solid circles in Fig. 1; the titre was decreased to less than $10 \%$ of the control value by rutilantin $0.1 \mu \mathrm{g} . / \mathrm{ml}$. and to less than $1 \%$ by $0.2 \mu \mathrm{g} . / \mathrm{ml}$. In gel diffusion tests against rabbitpox antiserum, extracts of cells infected in the presence of rutilantin 0.1 or $0.2 \mu \mathrm{g} . / \mathrm{ml}$. gave a pattern of precipitin lines indistinguishable from that produced by the control, though higher concentrations of rutilantin did prevent or decrease the formation of many antigens. The results suggested that, while minimum inhibitory concentrations of rutilantin did not suppress soluble antigen synthesis, this was progressively affected as the concentration of drug was increased. It seemed also that the inhibition was selective for certain antigens.

Action on synthesis of viral $D N A$. Cell cultures on coverslips were infected with virus of titre $10^{8}$ p.f.u. $/ \mathrm{ml}$. and then incubated in normal medium or medium containing rutilantin $0.2,0.4$ or $0.8 \mu \mathrm{g} . / \mathrm{ml}$. All three concentrations of drug caused complete inhibition of virus multiplication as judged by the yield of infective virus at $24 \mathrm{hr}$. Sample coverslips were withdrawn at intervals, stained with acridine orange, and examined under ultraviolet illumination for green-fluorescing inclusions of DNA. Almost all cells of the control cultures developed multiple small DNA foci; these increased in size, and by $24 \mathrm{hr}$ had diffused through most of the cytoplasm. In the presence of rutilantin $\mathbf{0 \cdot 2} \mu \mathrm{g}$. $/ \mathrm{ml}$., the development of foci was indistinguishable from that in normal medium. Higher concentrations of rutilantin did decrease DNA synthesis, though even in the presence of $0.8 \mu \mathrm{g} . / \mathrm{ml}$. some inclusions were seen in many of the cells. It is therefore unlikely that rutilantin inhibits the growth of rabbitpox virus by preventing the synthesis of viral DNA.

Table 3. The toxicity of rutilantin for mice

\begin{tabular}{|c|c|c|c|c|c|c|}
\hline \multirow{4}{*}{$\begin{array}{l}\text { No. of } \\
\text { mice }\end{array}$} & \multirow{2}{*}{\multicolumn{2}{|c|}{$\begin{array}{c}\text { Dose of } \\
\text { rutilantin (mg.) }\end{array}$}} & & & & \\
\hline & & & 1 & 2 & 3 & 7 \\
\hline & & & \multirow{2}{*}{\multicolumn{4}{|c|}{ Total deaths }} \\
\hline & Per mouse & Per kg. & & & & \\
\hline 10 & $0 \cdot 2$ & 10 & 0 & 5 & 5 & 7 \\
\hline 10 & $0 \cdot 4$ & 20 & 0 & 7 & 8 & 9 \\
\hline 10 & 0.8 & 40 & 6 & 10 & - & - \\
\hline 10 & $1 \cdot 2$ & 60 & 10 & - & - & - \\
\hline
\end{tabular}

\section{In vivo toxicity of rutilantin}

To determine whether the toxicity of rutilantin for cells in culture was reflected by a similar toxicity in vivo, four groups of ten mice ( $20 \mathrm{~g}$. body weight) were inoculated intraperitoneally with doses of rutilantin ranging from $0 \cdot 2$ to $1.2 \mathrm{mg}$. The mice were observed for 7 days, and moribund animals were killed and autopsied. The results of this experiment are presented in Table 3. Histological examination of autopsy material showed that the main damage occurred in liver and kidney. The liver showed acute toxic hepatitis, marked by dilation and congestion of the hepatic sinusoids. There was diffuse parenchymatous degeneration with fatty changes and 
a variable degree of necrosis. The kidneys showed acute toxic nephritis with widespread fatty changes, and frank tubular degeneration, with necrosis, was present mainly in the proximal convoluted tubules. The glomerular capillaries were dilated and congested, and there were focal haemorrhages mainly in the papillary zone.

In a second experiment, ten albino rabbits ( $2 \mathrm{~kg}$. body weight) were each inoculated intraperitoneally with $20 \mathrm{mg}$. rutilantin $(10 \mathrm{mg} . / \mathrm{kg}$.). Seven of the animals developed severe diarrhoea, and died within $48 \mathrm{hr}$. At autopsy these animals showed acute toxic lesions very similar to those seen in mice, the liver and kidney being severely damaged. The remaining three rabbits survived without evident ill-effects. They were killed after 7 days, and all organs appeared healthy. Rutilantin was therefore extremely toxic to mice and rabbits at doses only about 20 times greater than those needed to inhibit virus growth under the ideal conditions of tissue culture.

\section{DISCUSSION}

Rutilantin A was selected as a possible antiviral agent because of its proved activity against bacteriophage. The work reported here was undertaken initially to resolve conflicting reports about its inhibitory action against various animal viruses. In view of the extreme and apparently irreversible toxicity of the compound, the investigation was not extended to include therapeutic trials in animals.

Although the therapeutic use of rutilantin is not practicable, the substance possesses considerable interest as an inhibitor of rabbit pox virus replication. In minimal inhibitory concentrations, rutilantin apparently does not affect the formation of viral DNA nor that of soluble viral antigens. This indicates that the inhibition is directed against a late stage of the replication cycle, a suggestion which is confirmed by the fact that the drug was completely effective even when added late in the eclipse phase. The site of action of rutilantin is probably different from that of other known inhibitors of rabbit pox virus growth, none of which has been shown to act so late in the growth cycle. At higher concentrations, rutilantin also affected other processes occurring during virus development; the formation of many soluble antigens was prevented, and there was considerable inhibition of DNA synthesis.

The biochemical mode of action of rutilantin is unknown. The toxicity of the compound suggests that its effect on virus replication may be merely a reflexion of the irreversible damage that it causes to cell metabolism. This idea is supported by the observation that the capacity of cells to support virus growth was abolished by temporary exposure to rutilantin before infection. On the other hand, the relatively great sensitivity of the stage of growth occurring shortly before virus maturation suggests that minimal concentrations of the drug may have a more specifically antiviral action. In view of the advanced state of knowledge concerning the structure of rutilantin (Ollis \& Sutherland, 1961), this possibility invites further investigation. If the antibiotic could be detoxified without destroying its antiviral action, not only would its value in the laboratory and as a possible chemotherapeutic agent be enormously enhanced, but valuable information might be obtained about its mode of action relative to chemical structure.

The authors are indebted to Mr J. Randles and Dr D. W. Henderson, F.R.S. for the data on the in vivo toxicity of rutilantin, and to Miss H. J. Way for technical assistance. 


\section{REFERENCES}

Appleyard, G. \& Westwood, J. C. N. (1964). The growth of rabbitpox virus in tissue culture. J. gen. Microbiol. 37, 3.

Asheshov, I. N. \& Gondon, J. J. (1961). Rutilantin: an antibiotic substance with antiphage activity. Biochem. $J .81,101$.

Asheshov, I. N., Strentz, F., Hall, E. \& Flon, H. (1954). A survey of Actinomycetes for anti-phage activity. Antibiot. Chemother. 4, 380.

Cooper, P. D. (1955). A method for producing plaques in agar suspensions of animal cells. Virology, 1, 397.

Crowle, A. J. (1958). A simplified micro double-diffusion agar precipitin technique. J. Lab. clin. Med. 52, 784.

Ollis, W. D. \& Sutherland, I. O. (1961). A new family of antibiotics. In Recent Developments in the Chemistry of Natural Phenolic Compounds. Ed. by W. D. Ollis. Oxford and London: Pergamon Press.

RANDlES, W. J. (1960). Induced fluorescence with acridine orange, after osmium fixation. Nature, Lond. 187, 964. 
